\title{
BOOK REVIEW •
}

Jelisaveta Petrović and Vera Backović (2019). Experiencing Postsocialist Capitalism: Urban Changes and Challenges in Serbia (250 pages). Belgrade: University of Belgrade - Faculty of Philosophy. ISBN 978-86-6427-136-3.

Reviewed by: Moisés Muguerza-Espino. Transport Planner. Warwickshire County Council in England. muguerza.m@icloud.com

https://doi.org/10.47785/urbana.11.2021

This book centres in how the evolution of the city and the different actors are perceived by the people from the inside of the situation in Serbia and focusing on the case of Belgrade Waterfront. Part I of the book starts by presenting a definition of the terminology used, giving a background on the evolution of the social and political situation in Serbia in general and how the government has acted in response to the country's necessities along the year. Part II continues with more detail on the Belgrade situation and the reaction of the people affected by the development of the Belgarde Waterfront project. The selection of chapters gives a full panorama of the political situation in Serbia and the context that Belgrade is facing, making this a comprehensive analysis directly from the voice of the actors. Even when the books centres in the analysis of the impact of neoliberal markets in Eastern Europe, it can be applied to other regions experiencing the beginning or consolidation of neoliberalism, and it is good as a reflexion for urbanists in how this type of projects affect the people who live in the areas to be redeveloped.

The Creative Culture and Gentrification have been synonyms of displacement in current regeneration programs in cities around the world. During the current postindustrialisation age many of the western cities started experiencing gentrification in different forms, and depending the motivation of the stakeholders, it can deliver benefits to the many or to the few. In the first chapter, Backovic (2019) starts the first chapter of the book with a comprehensive classification of the different stages of gentrification in the chapter "The Specificity of Gentrification in the Postsocialist City: The Case of the Belgrade Waterfront Project", and how this stages have been developing in Belgrade Waterfront project in the quarter of Savamala. Therefore, it defines pioneering gentrification as an authentic regeneration of industrial areas which have been abandoned by the evolution of the city, and distinguishing what is named as profitable gentrification which is lead mainly by capital. This first chapter helps the reader to set the background needed for the rest of the book by defining the different terminology which other authors refer in their own chapters and help non-related professionals to get the basic knowledge to understand the book.

The brand of "Capital of Culture" was previously attributed only to big cities. But after Glasgow's success as CoC in 1960, which previously was considered a derelict post-industrial city, other post-industrial cities started by suing this recipe as catalysator to modernise cities. In the "Struggling with the Title: A Capital of Culture at the Superperiphery Of Europe", Pajvančić - Cizelj (2019) details on the creation of creative neighbourhoods and cultural districts and how this creates displacement of the most vulnerable sectors of the society. And while there is no solid evidence on the benefits of these recipes applied by different governments around the world, the case of Novi Sad 2021/22 shows a big part of the impact on the residents. Therefore, the author suggests further analysis should be done before presenting any conclusions about it and before proposing this a solution to every postindustrial city.

The evolution of the quarter of Savamala which started being pioneering gentrification, and then due to the potential profits that could be gained a section of this 
neighbourhood transformation into profitable gentrification, is detailed by Lazić (2019) in "The Role of the Civil Sector in the Urban Transformation of the Savamala Neighbourhood" contained in the second part of the book. The author explains the different organisations that have used the space, which most of them tend to be from the creative sector and entrepreneurial. According to the analysis done by the author, the type of gentrification that was originally surging in the area was "pioneer gentrification". Nevertheless, given the lack of continuity of funding for the established in the area and the success of the first gentrifications, the whole site was seemed as an attractive area to investors. This leaded to the creation of the Belgrade Waterfront project, displacing the pioneer gentrifiers. Must be acknowledged that Glasgow in particular has continued promoting the city by different means which is key part for successful implementation would be continuity of projects, and a comprehensive planning of the ex-post phase, which has continued until recent years with the Commonwealth Games in 2016. The Belgrade Waterfront project is giving the continuity needed to the development of the area as done in Glasgow but lacking community engagement, and according to this book, passing over the interest of the residents.

While the first and last chapters of the book discusses the different stages of Savamala regeneration, the core of the book presents the analysis of both sides of the main actors of the conflict with a stronger support in the opposition to the Belgrade Waterfront project. In the second chapter "Behind the Frontline of the Belgrade Waterfront: A Reconstruction of the Early Implementation Phase of a Transnational Real Estate Development Project", Koelemaij and Janković (2019) present a qualitative research which starts by describing the origins of the speculative developments in the 80 's in the United States, where "contrary to what Neoliberalism states" the government takes high risks in order to position their cities in what the book defines as "municipal mercantilisms". The government in Serbia achieved an urban entrepreneurialism by "boosting" the economy of the area, and placing the Belgrade in the map, which main objective is to impress rather than bringing benefits to the local community. The authors also analyse that these projects tend to help actors to "jump" from the private sector to the public sector into different position of power, and that while investors might not get high profits, it could be a way of control and expansion of "their territory". While the author condemns municipal mercantilism, this has been a good source of income for developing the cities. In more developed economies, attracted developers are required to fund social programs and community orientated development schemes. Nevertheless, from the author's perspective no wider investment has been promoted to benefit others than the investors which leads to the idea of corruption behind it, especially because it is deducted that no benefit would be either achieved by the developers either. While the corporative and governments' motivations could be real, individual motivations are yet to be explored.

The book also analyses that while government tries to sell the city quarter of Savamala to the private sector, they have been facing opposition from members of the public. In "The Transformative Power of Urban Movements on the European Periphery: The Case Of The Don't Let Belgrade D(R)Own Initiative" by Petrović (2019) and "The Participants in the Protest Against Illegal Demolitions in Belgrade's Savamala Quarter" by Nikolić (2019), the different factors that have led to people to organise an claim their rights in the places they live, work and commute is analysed. Nikolić analysed the identify their level of education, reasons for participating in the protest, ideas on how to solve the problem, their goals of participating in the protest, and if they had political engagement. While Petrović analysed the evolution and hierarchisation of the Don't Let Belgrade D(R)Own Initiative. This claim of the city and "who the city belongs to", are also analysed in the final chapter "The Transformative Power of Urban Movements on the European Periphery: The Case Of The Don't Let Belgrade D(R)Own Initiative" by Čabrilo (2019). By interviewing different street artists, Čabrilo concludes that while the street artists use their paintings as a way to claiming 
the city, and are involved in the process of redefining the space; they also paint for profit, being therefore part of the capitalist system, but after gaining some experience in the area, with the capacity of drive their art to express their ideology. These movements are key for the bottom-up planning, and while might be seen negative by Serbia's national government, local government and future politics could be shaped by them. Moreover, there is always the need of opposition for any proposal, as this guarantees that more voices would be heard.

The remanent of the war and socialist period of Serbia is still present as the main force that has driven the current situation in the country as analysed in all the other chapters. This book compiles different articles which give a full panorama of the life in Belgrade and Serbia in general, and succeeds to give a comprehensive background of the social and political situation of Belgrade Waterfront project directly from the affected people. Therefore, making this book worthy to take in consideration as an experience to visualize what we would like to achieve in our cities for the benefit of the many which can be applied to other places with different levels of complexity. Further research should include analysing the counterparts of the affected people (corporations, and national government). Furthermore, an analysis of the evolution and outcomes of the project would be necessary to produce a critical analysis.

\section{References}

Backović, V. (2019). The Speificity of Gentrification in the Postsocialist City: The Case of the Belgrade Waterfront Project. In J. Petrović, \& V. Backović, Experiencing Postsocialist Capitalism: Urban Changes and Challenges in Serbia (pp. 23 - 44). Belgrade: University of Belgrade - Faculty of Philosophy.

Cabrilo, M. (2019). The Transformative Power of Urban Movements on the European Periphery: The Case Of The Don't Let Belgrade D(R)Own Initiative. In J. Petrović, \& V. Backović, Experiencing Postsocialist Capitalism: Urban Changes and Challenges in Serbia (pp. 229 - 249). Belgrade: University of Belgrade - Faculty of Philosophy.

Cizelj, A. P. (2019). Struggling with the Title: A Capital of Culture. In J. Petrović, \& V. Backović, Experiencing Postsocialist Capitalism: Urban Changes and Challenges in Serbia (pp. 127 - 150). Belgrade: University of Belgrade - Faculty of Philosophy.

Janković, J. K. (2019). Behind the Frontline of the Belgrade Waterfront: A Reconstruction of the Early Implementation Phase of a Transnational Real Estate Development Project. In J. Petrović, \& V. Backović, Experiencing Postsocialist Capitalism: Urban Changes and Challenges in Serbia (pp. 45 - 66). Belgrade: University of Belgrade - Faculty of Philosophy.

Lazić, S. (2019). The Role of the Civil Sector in the Urban Transformation. In J. Petrović, \& V. Backović, Experiencing Postsocialist Capitalism: Urban Changes and Challenges in Serbia (pp. 211 - 228). Belgrade: University of Belgrade - Faculty of Philosophy.

Nikolić, M. (2019). The Participants in the Protest Against Illegal Demolitions in Belgrade's Savamala Quarter. In J. Petrović, \& V. Backović, Experiencing Postsocialist Capitalism: Urban Changes and Challenges in Serbia (pp. 189 - 2010). Belgrade: University of Belgrade - Faculty of Philosophy.

Petrović, J. (2019). The Transformative Power of Urban Movements on the European Periphery: The Case Of The Don't Let Belgrade D(R)Own Initiative. In J. Petrović, \& V. Backović, Experiencing Postsocialist Capitalism: Urban Changes and Challenges in Serbia (pp. 171 - 188). Belgrade: University of Belgrade - Faculty of Philosophy. 